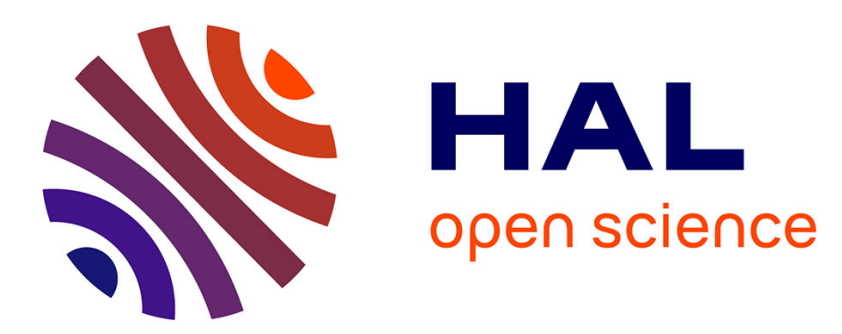

\title{
HIGH TEMPERATURE PROPERTIES OF LASER ALLOYED TITANIUM
}

\author{
A. Fasasi, M. Pons, A. Galerie
}

\section{To cite this version:}

A. Fasasi, M. Pons, A. Galerie. HIGH TEMPERATURE PROPERTIES OF LASER ALLOYED TITANIUM. Journal de Physique IV Proceedings, 1991, 01 (C7), pp.C7-55-C7-59. 10.1051/jp4:1991712 . jpa-00250769

\section{HAL Id: jpa-00250769 https://hal.science/jpa-00250769}

Submitted on 1 Jan 1991

HAL is a multi-disciplinary open access archive for the deposit and dissemination of scientific research documents, whether they are published or not. The documents may come from teaching and research institutions in France or abroad, or from public or private research centers.
L'archive ouverte pluridisciplinaire HAL, est destinée au dépôt et à la diffusion de documents scientifiques de niveau recherche, publiés ou non, émanant des établissements d'enseignement et de recherche français ou étrangers, des laboratoires publics ou privés. 


\title{
HIGH TEMPERATURE PROPERTIES OF LASER ALLOYED TITANIUM
}

\author{
A. FASASI, M. PONS and A. GALERIE
}

Laboratoire Science des Surfaces et Matériaux Carbonés, URA CNRS n ${ }^{\circ} 413$, ENS d'Electrochimie et d'Electrométallurgie de Grenoble, Institut National Polytechnique de Grenoble, BP. 75, Domaine Universitaire, F-38402 St-Martin d'Hères, France

\begin{abstract}
Surface alloys are of great interest for improving the mechanical and/or chemical properties of the near surface region of metallic materials. Surface alloy formation by laser melting involves the base metal and one or several foreign elements, introduced either in a predeposited slurry or directly in the melt pool by the means of a power feeder.

Surface alloys were produced on titanium by laser irradiation of predeposited aluminium and silicon powders. It was observed that hardness increased with silicon content and carbon dissolution. The maximum value achieved was as high as $1100 \mathrm{Hv}$ without the presence of carbon. It was also observed that laser aluminization improved isothermal as well as cyclic oxidation resistance while the presence of carbon was detrimental. The addition of silicon led to a decrease of the minimum concentration of aluminium necessary to form a continous and protective layer of $\mathrm{Al}_{2} \mathrm{O}_{3}$.
\end{abstract}

\section{INTRODUCTION}

The earlier works on ligh temperature oxidation kinetics of bulk Ti-Al alloys $(1,2)$ have shown that 25 to 64 atom \% aluminium is necessary to have a distinct formation of $\mathrm{Al}_{2} \mathrm{O}_{3}$ on the surface of this alloy. The titanium aluminides like $\mathrm{Ti}_{3} \mathrm{Al}$ and $\mathrm{TiAl}$ have good strengths but cannot withstand temperature greater than 923 and $1313 \mathrm{~K}$ respectively in an oxidizing environment.

Addition of silicon to titanium $(3,4)$ improved its resistance to scaling due to the formation of a protective silica layer which prevents the inward diffusion of oxygen.

The use of laser on direct write metalisation for microelectronic purposes using polymeric substances has been going on for some time (5) but it is only recently that Pons et al. (6) presented a new working possibility which consisted of chemical reduction of metal salts in polymers, followed by alloying in the liquid state.

Here, we describe simultaneous aluminization and siliconization of a commercial titanium alloy (TA6V4) by laser melting for modification of its surface properties like microhardness and oxidation resistance.

\section{EXPERIMENTAL PROCEDURES}

Alcoholic and polymeric mixtures of aluminium and silicon were used. The preparation of the alcoholic mixture and the characteristics of the laser employed has been described elsewhere (7). In the polymeric mixture, $2 \mathrm{~g}$ of aluminium, $1,4 \mathrm{~g}$ of silicon were mixed with 3 $\mathrm{g}$ of polyethylene glycol (PEG). The mixture was heated to the melting point of the polymer $(343 \mathrm{~K})$, brushed onto the $1200 \mathrm{SiC}$ grit polished TA6V4 specimens of $1.5 \times 1.3 \times 0.3 \mathrm{~cm}$ dimension and left to dry in air. The thickness of the deposited layers were \# $200 \mu \mathrm{m}$. 


\section{CHARACTERIZATION OF THE ALLOYS}

Experiments have shown that a beam power of $150 \mathrm{~W}$ with a scanning speed of 4 $\mathrm{mm} / \mathrm{s}$ was sufficient to achieve Ti-Al-Si alloys of different compositions with the best homogeneity. Most of the results presented here have been obtained with this power.

\subsection{Compositon}

With the alcoholic mixtures, seven different compositions were prepared with increasing silicon content. The general trend was that the aluminium content of the alloys decreased when the content of silicon increased. This is due to the high absorptivity of light by silicon compared to aluminium, leading to an increase of the melt depth. Observation by scanning electron microscope (SEM) showed indeed that the thickness of the surface alloys increased from \# $120 \mu \mathrm{m}$ in the sample without silicon (Ti-40AI) to \# $200 \mu \mathrm{m}$ in the sample containing the maximum amount of silicon (Ti-20Al-9,5Si).

Electron microprobe analysis on the surface of the alloy prepared from polymeric mixture showed the composition to be Ti-15Al-4Si with the thickness of \# $250 \mu \mathrm{m}$ compared to \# $200 \mu \mathrm{m}$ for alcoholic mixture. This could be due to the decomposition of PEG to carbon and volatile constituents. The presence of carbon at the surface increased the absorptivity of the incident energetic photons, which led to an increase in the melt depth (figures la-b).

\subsection{Cristalline nature}

X-ray diffraction analyses showed the presence of $\mathrm{Ti}_{5} \mathrm{Si}_{3}$ and $\mathrm{Ti}_{3} \mathrm{Al}$ phases in all the silicon containing surface alloys which is in good agreement with the Ti-Al and Ti-Si phase diagrams observed separately. When silicon is absent ( $\mathrm{Ti}-40 \mathrm{Al})$, TiAl 3 appeared in addition to $\mathrm{Ti}_{3} \mathrm{Al}$ showing the non-equilibrium nature of this coating. With $\mathrm{PEG}$, an additional phase, Tic, appeared.

\subsection{Microstructure}

The surface alloys obtained from the alcoholic mixtures were homogeneous but polyphased while alloys formed from polymeric mixtures showed a high degree of nonequilibrium solidification with the formation of dendrites (figures la-b). The $\mathrm{Ti}_{5} \mathrm{Si}_{3}$ phase appeared typically faceted in the form of plates (d 非 $5 \mu \mathrm{m})$ or of interconnected fibres (10-20 $\mu \mathrm{m}$ in length). The aluminide phase was surrounded by the silicide phase. The features were generally more refined near the surface of the samples. Cracks, the usual consequence of laser treatments, were absent.

\subsection{Microhardness}

The result, shown in (figure 2) on the Identation Size Effect, can be summarized as follows : (i) Ti-40Al was harder than unalloyed TA6V4, (ii) addition of silicon further increased the hardness and (iii) the incorporation of carbon allowed the hardness of Ti-15AI$4 \mathrm{Si}$ to be higher than the others. It is also noticed that laser alloyed materials exhibit a decreasing hardness when the load increases, contrary to what is observed with unalloyed materials.

\section{OXIDATION (Isothermal and cyclic)}

Isothermal oxidation tests were performed between 1023 and $1183 \mathrm{~K}$ in air at atmospheric pressure on samples Ti-20Al-9,5Si and Ti-15Al-4Si. Figure 3, is the comparison of the oxidation resistance of the two systems. The kinetics are parabolic and the activation energies in the temperature range studied are 260 and $160 \mathrm{~kJ} / \mathrm{mol}$ for the two samples respectively.

Cyclic oxidation tests were performed at a plateau of $1183 \mathrm{~K}$ with a heating rate of $1173 \mathrm{~K} /$ hour and a cooling rate of $723 \mathrm{~K} /$ hour. The plateau was held for 24 hours. Four cycles were performed for samples Ti-40Al, Ti-20Al-9.5Si and Ti-15Al-4Si. Ti-20Al-9.5Si loses about ten times less weight than the other two and exhibits a better behaviour (figure 4). SEM observations confirm the beneficial influence of silicon on the spallation of the oxide scales. 

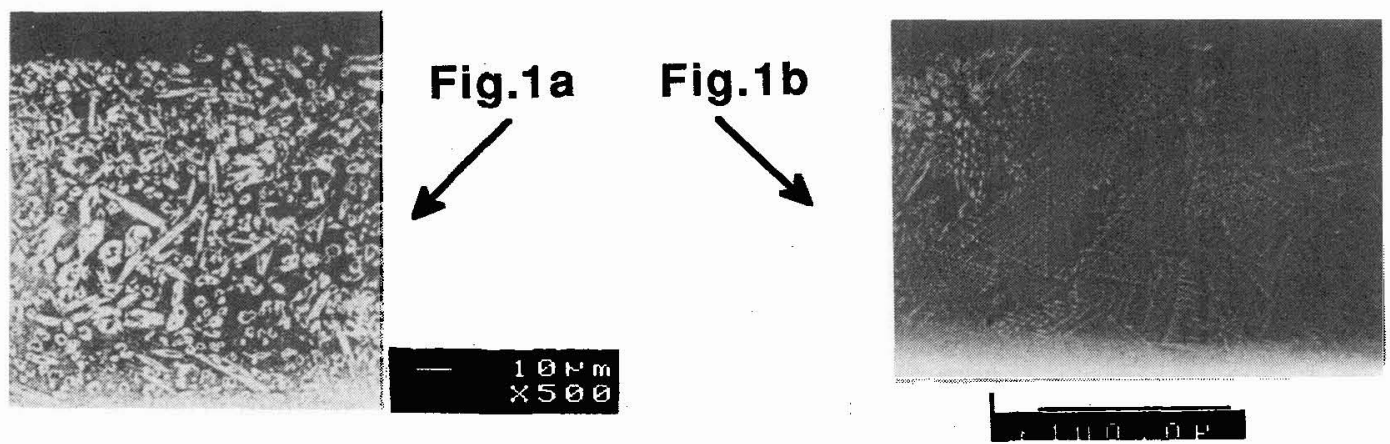

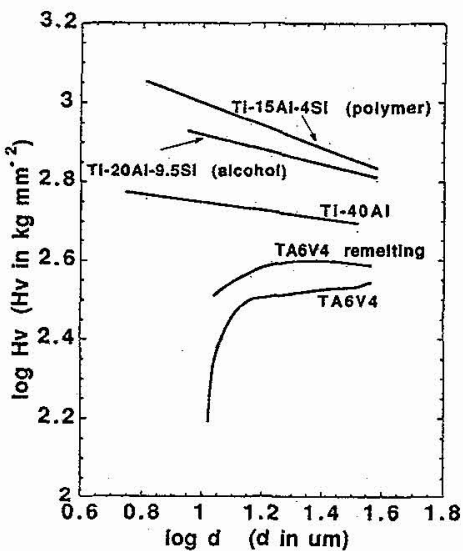

Fig. 2

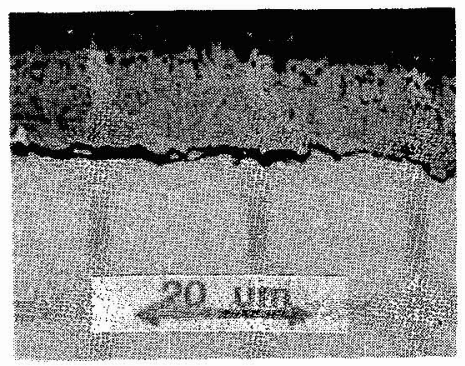

Fig.5a

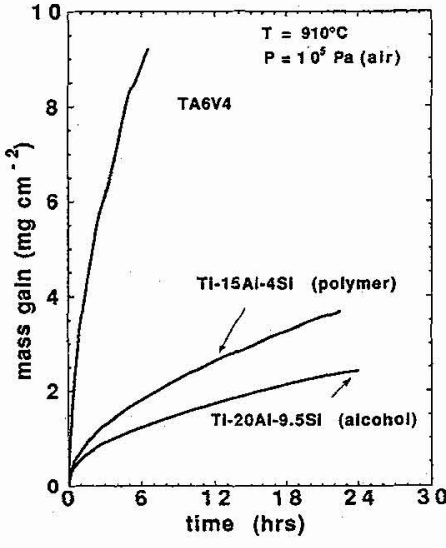

Fig.3

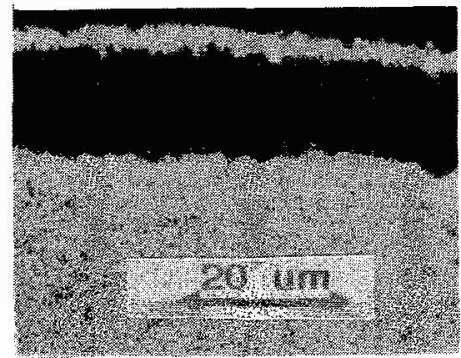

Fig.5b

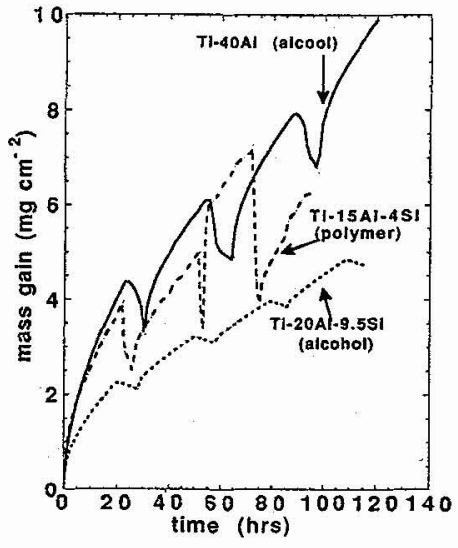

Fig.4

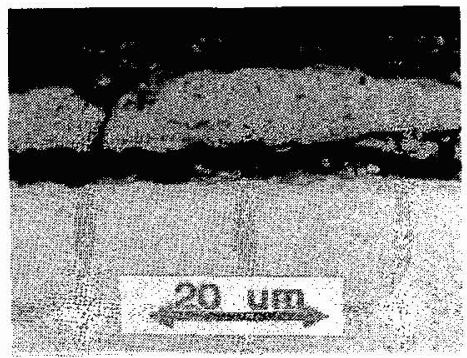

Fig. 6

Fig. 1 : SEM micrographs of the transverse section of the surface alloy prepared from

(a) alcoholic mixture (Ti-20Al-9.5Si) and (b) polymeric mixture (Ti-15Al-4Si).

Fig. 2 : Applied load as a function of identation diagonal for different alloys with a view of obtaining the Identation Size Effect.

Fig. 3 : Oxidation kinetics of alloyed and unalloyed TA6V4 at $1183 \mathrm{~K}$ in air.

Fig. 4 : Cyclic oxidation tests for Ti-40Al, Ti-20Al-9.5Si and Ti-15Al-4Si.

Fig. 5 : (a) Transverse section of the oxide scale formed on Ti-20Al-9.5Si at $1183 \mathrm{~K}$ during 100 hours, (b) X-ray image for aluminium.

Fig. 6 : Transverse section of oxide scale formed on Ti-15Al-4Si at $1183 \mathrm{~K}$ during 5 hours showing the formation of cracks. 


\subsection{Characterization of the oxide scales}

4.1.1. X-ray diffraction analysis

The scale on Ti-20Al-9.5Si showed the presence of oxides like $\mathrm{TiO}_{2}, \mathrm{Al}_{2} \mathrm{O}_{3}$ and $\mathrm{SiO}_{2}$ while that on Ti-15Al-4Si exhibited the presence of additional unreacted ${ }^{2} \mathrm{Ti}_{2}$ in addition to these binary oxides.

\subsubsection{Microstructure}

The oxide scales formed were compact and adherent except for Ti-40Al and Ti-15Al$4 \mathrm{Si}$ where the scales showed a high tendency to spall. The scales on Ti-20Al-9.5Si (figures $5 \mathrm{a}-\mathrm{b}$ ) and Ti-15Al-4Si (figure 6) consisted of three sublayers :

- an external $\mathrm{Al}_{2} \mathrm{O}_{3}$ sublayer, in contact with the gas, containing $\mathrm{TiO}_{2}$ in the case

- an intermediate sublayer, containing $\mathrm{SiO}_{2}$ and $\mathrm{TiO}_{2}$,

- an internal sublayer, in contact with the surface alloy, containing a high concentration of unoxidised aluminium.

To explain the presence of $\mathrm{Al}_{2} \mathrm{O}_{3}$ and $\mathrm{TiO}_{2}$ at the surface of $\mathrm{Ti}-15 \mathrm{Al}-4 \mathrm{Si}$, oxidation tests were performed at different oxidation times, ranging from 5 to 100 hours. After 5 hours of oxidation, cracks and holes were observed in the oxide layer. This may be possibly due to a chemical reaction between $\mathrm{TiC}$ and $\mathrm{O}_{2}$ (from thermodynamic point of view, this reaction is possible at $1173 \mathrm{~K})$ as represented :

$$
\mathrm{TiC}+1 / 2 \mathrm{O}_{2} \rightleftharpoons \mathrm{CO}+\mathrm{Ti}
$$

The carbon monoxide so formed could only escape to the surface by crack formation. These cracks are easy diffusion paths for inward penetration of oxygen. The ease at which oxygen penetrates this carbonaceous alloy is manifested by the thickness of the external $\mathrm{Al}_{2} \mathrm{O}_{3}$ which is $10 \mu \mathrm{m}$ compared to $6 \mu \mathrm{m}$ for $\mathrm{Ti}-20 \mathrm{Al}-9.5 \mathrm{Si}$.

As observed with Fe-Cr-Al and Cu-Zn-Al alloys (8), the initial stage of oxidation here is the simultaneous nucleation of $\mathrm{TiO}_{2}, \mathrm{SiO}_{2} \cdot$ Moreover, in the presence of sufficient quantity of aluminium in the alloy, the initially formed $\mathrm{TiO}_{2}$ and $\mathrm{SiO}_{2}$ will be reduced by aluminium through displacement reactions according to :

$$
\begin{aligned}
& 4 \underline{\mathrm{Al}}+3 \mathrm{TiO}_{2}=3 \underline{\mathrm{Ti}} \text { (in the alloy) }+2 \mathrm{Al}_{2} \mathrm{O}_{3} \\
& { }^{4} \mathrm{Al}+3 \mathrm{SiO}_{2}=3 \underline{\mathrm{Si}} \text { (in the alloy) }+2 \mathrm{Al}_{2} \mathrm{O}_{3}
\end{aligned}
$$

The titanium and silicon so released, formed the observed underneath sublayer with pure $\mathrm{Al}_{2} \mathrm{O}_{3}$ on the top surface. Therefore, it may be concluded here that silicon blocks the inward diffusion of oxygen and its subsequent dissolution in the surface alloy by forming an intermediate $\mathrm{SiO}_{2}$ sublayer.

The scale morphology as observed is compatible with the idea of simultaneous inward transport of oxygen and outward diffusion of $\mathrm{Al}^{3+}$. The external $\mathrm{Al}_{2} \mathrm{O}_{3}$ sublayer grows parabolically by outward cationic diffusion and is thought to provide sufficient barrier to the ingress of oxygen. One can therefore understand why the overall rate law is parabolic. For Ti-20Al-9.5 Si, the internal $\mathrm{SiO}_{2}$ promotes the formation of an external alumina sublayer but contributes also to the plasticity of the scale, as demonstrated by cyclic oxidation tests.

\section{CONCLUSION}

The possibility of elaboration of surface alloys on TA6V4 with different aluminium and silicon concentration by laser melting was demonstrated and conditions described. The surface alloys in the absence of carbon exhibit interesting properties like improved hardness, good adherence and slow oxidation. The beneficial effect of silicon was revealed on the oxidation kinetics as well as on the adherence of the oxide scale. Also, addition of silicon reduced the amount of aluminium necessary to form a continous scale of $\mathrm{Al}_{2} \mathrm{O}_{3}$ on the surface of titanium. The presence of carbon further increases the hardness but this element is detrimental to the oxidation resistance due to crack formation. Such surface alloys, allowing separate optimization of bulk and surface properties, are thought to take an important place in the future development of titanium alloys at high temperatures. 


\section{ACKNOWLEDGEMENTS}

This is part of the work of Fasasi. A for the obtention of the I.N.P.G. doctorate. He wishes to thank C.N.O.U.S. (Centre National des Oeuvres Universitaire et Scolaire) for the award of a 4 year scholarship.

\section{REFERENCES}

1. Meier G.H., Appalonia B., Perkins R.A., Chiang K.T. "Oxidation of High Temperature Intermetallics", Edited by Grobstein, T. Doychak, J. T.M.S., Warrendale, Pa (1989) 185.

2. Perkins, R.A., Chiang, K.T., Meier, G.H., Miller, R., in reference 1, pp 207. 3. Rosa, C.J., "Oxid. Met." 17 (1982) 359.

4. Chaze, A.M., Coddet, C., "Oxid. Met." 27 (1987) 1.

5. Gross, M., Appelbaum, A., Gallagher, P.K., "J. Appl. Phys.", 61 (1987) 1628.

6. Pons, M., Hugon, A., Galerie, A., Fasasi, A., Sugier, A., "Surf. Coat. Techn.", to be published (1991).

7. Galerie, A., Fasasi, A., Pons, M., Caillet, M., "Surface Modification Technology V", to be published (1991).

8. Wagner, C., "Corrosion Science", 5 (1965) 751. 